\title{
An Estimate of Tax Evasion in Croatia
}

\section{Madžarević-Šujster, Sanja}

Source / Izvornik: Occasional Paper Series, 2002, 6, 1 - 23

Journal article, Published version

Rad u časopisu, Objavljena verzija rada (izdavačev PDF)

https://doi.org/10.3326/ops.13

Permanent link / Trajna poveznica: https://urn.nsk.hr/urn:nbn:hr:242:354380

Rights / Prava: Attribution-NonCommercial-NoDerivatives 4.0 International/ImenovanjeNekomercijalno-Bez prerada 4.0 međunarodna

Download date / Datum preuzimanja: 2023-04-26

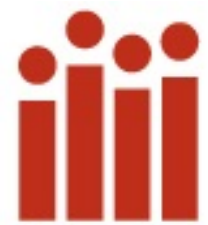




\title{
AN ESTIMATE OF TAX EVASION IN CROATIA
}

\author{
Sanja Madžarević-Šujster
}

Occasional Paper No. 13

April 2002

@ Institute of Public Finance 2002 


\title{
AN ESTIMATE OF TAX EVASION IN CROATIA
}

\author{
Sanja Madžarević-Šujster \\ World Bank, Zagreb, Croatia
}

\begin{abstract}
The definition of the underground economy in this work is a legal economic activity that is not reported for the purpose of avoiding the payment of taxation; the tax defaulter thus increasing his own personal benefit. Tax evasion is an unlawful manner of reducing the tax liability: for example, underreporting the income made or by stating inflated business deductions. In the case of tax avoidance, however, the taxpayer simply makes use of the opportunities provided in the law for the reduction of his or her tax liability. The consequence of an increase in evasion is the erosion of the tax base. A shortfall in revenue collected will result in a deficit that can be financed either by a further increase in taxation, which ultimately deepens the size of the underground economy and the inclination to evasion, or by borrowing, placing an extra burden on future taxpayers.

The stability of the tax system is an important factor in the reduction of tax evasion. The transitional environment, however, with its dynamics and a number of changes in the tax and economic systems has a negative effect on a reduction in the extent of tax evasion. In the environment of the adjustment of taxation systems to the market economy, the broadening of the tax base, the introduction of new and the abolition of old taxes and of changes in the tax rates, it is hard to make reliable conclusions about the extent of tax evasion. Through a separate analysis of the evasion of some direct and indirect taxes for the 1994-2000 period, two estimates have been obtained: the lower estimate of tax evasion, which approximately follows the trend in the underground economy (UE) as a percentage of GDP, and ranges about $5.5 \%$ of GDP; and the upper estimate, which partially follows the trend in the overall tax burden of the economy, and was considerably reduced after 1998 with a reduction of the payroll taxes, that ranges from about 11 to about $7.5 \%$ of GDP in 2000 .

A decision to resort to evasion is very easily taken in an unstable environment, while for an irreversible process, though promising, tax defaulters need a critical mass of positive reforms and a relatively long period of time.
\end{abstract}

JEL Classification: $\mathrm{H} 26$

Key words: tax evasion, tax avoidance 


\section{AN ESTIMATE OF TAX EVASION IN CROATIA*}

\section{INTRODUCTION}

The question of tax evasion does not cease to be a part of the discussion at a daily political scene. It is the more topical in that the stagnant deficit of the state budget at the level of about $5.5 \%$ of GDP in 2000 and 2001 has become the major threat to macroeconomic stability. The redistribution of income that results from tax evasion causes the long term defaults of economic and social policy. The government, for example, can find itself in the situation of paying the guaranteed minimum pensions (which are currently $70 \%$ subsidised as compared with the minimum contributions paid in) to persons who have already made greater income by working in the grey economy and today have large savings deposits abroad, or of paying child benefits to parents who are reported as having the minimum wages, but to whom wages are paid in cash that bring them above the means-tested eligibility level. Because of increased social spending, the government is forced either to increase the (usually) regressive kinds of taxes that are hard to avoid but relatively burden the poor more, or to seek solution in new borrowing that will place a burden on future generations of taxpayers. Thus, tax defaulters bring about greater poverty for today's and tomorrow's "honest" taxpayers.

The subject of this research is an estimate of the tax evasion in Croatia between 1994 and 2000. The research starts by defining the difference between tax evasion and tax avoidance; some typical examples of tax evasion are given together with the usual ways of lawfully avoiding tax liability. Some factors that affect the behaviour of taxpayers are the amount of the tax burden, the legislative burden, penalties for attempted tax evasion, the organisation of the taxation service, the likelihood of evasion being detected, the structure of public spending, the quality of public services, and general awareness of the need to pay taxes.

In the third chapter of the research an estimate is made of the potentially collected tax from some direct (income tax and surtax and contributions for social security, as well as profit tax) and indirect taxes (valued added tax, excise on tobacco). The estimate is given for the 1994-2000 period at two levels the upper and the lower, and is based on data from a household budget survey, a labour force survey, and data from the Tax Administration and the Institute for Payments. The author brings in additional assumptions that enable her to reveal the gap between tax collected and potentially collected tax. Considering the frequent changes in tax legislation, the temporal comparability of the calculation may be considered questionable, although, the trend of the lower estimate of tax evasion keeps up with the trend of the estimate of the UE (Madžarević and Mikulić, 2002). This is, of course, a logical result, because there is a strong correlation between the two phenomena.

The last and concluding chapter briefly describes a combined estimate of tax evasion and attempts to find an explanation for such a trend in evasion. The final part of the paper gives some economic policy recommendations.

\footnotetext{
* This article is published in Croatia in the journal "Financijska teorija i praksa", 26(1), 2002., pp.117-145. available at http://www.ijf.hr/financijska_praksa/PDF-2002/madzarevic-sujster.pdf.
} 


\section{THE CONCEPT OF TAX EVASION, THE MEASUREMENT AND THE FORMS IN WHICH IT APPEARS}

\subsection{The Concept of Evasion}

The definition of the underground economy in this work runs as follows: it concerns lawful economic activities that are not reported for the sake of avoidance tax payment, by which the tax defaulters increase their own personal benefit. Tax evasion is an unlawful way of reducing tax liabilities, for example, by underreporting income made or reporting inflated business deductions. It is important to differentiate between tax avoidance and tax evasion. Tax avoidance implies all those permitted lawful steps made in order to reduce or totally obviate the tax liability, making use of all the legal shortcomings and loopholes. In tax avoidance, then, the taxpayer simply makes use of the opportunities that the government gives him via the tax laws, while in tax evasion he takes the law into his own hand, and determines which part of the tax duty he/she will pay to the state according to his own system for evaluating justice.

In the literature, the word non-compliance is also used, which is similar in meaning to tax evasion, and implies deliberate or unintentional avoidance of the proper payment of taxes. Theoretical consumption models show that tax compliance falls with a fall in current income, growth in inflation and the expectation of greater income in the future. ${ }^{1}$ Tax flight is the concept for the avoidance of taxation that comes about by the re-registration of companies in areas with a lower tax burden or perhaps in tax oases, which is also a legitimate act on the part of the taxpayer, although in the opinion of the general public it is fairly immoral.

Since tax evasion, avoidance and flight have similar objectives - the reduction of the tax liability, and are guided by the same goal - the increase of one's own benefit, economists often analyse their effects together.

\subsection{The Measurement of Tax Evasion}

We distinguish direct and indirect measures of tax evasion. Tax evasion is most often estimated via a detailed check of tax returns (the direct method) but also common is the estimate of evasion via some of its macroeconomic aggregates, tax bases (the indirect method). Checking the tax returns is a demanding and expensive procedure, which does give information about the structure of evasion in a single year, but not about temporal trends.

The best way of combating tax evasion is an analysis of entrepreneurs' motivation for work in the UE. The main causes of evasion mentioned in the literature ${ }^{2}$ are high tax burden (in most research this accounts for as much as $60-70 \%$ of the UE), compliance costs, penalties for attempted tax evasion, the organisation of the tax service, the likelihood of being detected, general awareness about the need to pay taxes and the structure of public spending combined with the quality of public services (health, education, social security, legal protection, the infrastructure). These factors in the tax evasion measurement are used in the so-called causality method (an indirect method), where the trend of the UE (which is significantly correlated with tax evasion) is regressed over these variables.

In most researches an increase in tax evasion is significantly correlated with an increase in the total tax burden, especially of income tax and social security contributions. Other factors, such as the regulatory framework, administrative obstacles, the credibility of the legal system and the quality of public

\footnotetext{
${ }^{1}$ Fishlow and Friedman (1991) show that tax compliance is a function of the relation between current and permanent income, and that the taxpayer according to this ratio retains the optimum ratio of current and future consumption. At a moment in which current income is suddenly reduced (because of inflation or recession) the taxpayer only partially reduces current consumption and looks for new financial sources or decides against tax compliance.

${ }^{2}$ Pomerehne and Hanneman (1995).
} 
services also have a great effect on the trends in the grey economy and tax evasion. ${ }^{3}$ The consequence of increased evasion is the erosion of the tax bases. A shortfall in revenue collected results in a deficit that can be financed by further tax increases, which ultimately additionally deepens the extent of the grey economy and the tendency towards evasion.

Considering that taxes affect decisions about the allotment of the taxpayer's time into work and leisure periods, and stimulate the supply of labour on the grey or untaxed market, the distortion of work by taxes is one of the most common themes of economic analyses. The greater the wedge between total costs of work and net wages, the greater the motivation for the avoidance or evasion of taxes. Research has shown that not even large tax cuts will lead in the short term to any major reduction in the grey economy, but will perhaps stabilise it. Work in the underground sector correlates positively, apart from with the amount of the income taxation, with a reduction of work hours in the official sector, but negatively with the amount of wages in the official sector. That is, reduction of the work hours makes it possible to work longer in the UE, because in a given economy there is no restriction in the number of work hours. Early retirement and part-time work have the same effect.

The trend in evasion, apart from the above, is also significantly correlated with economic growth, and with changes in the standard of living of the population. In all research of the size of the grey economy (which is actually the base for tax evasion) it is clear that it moves in an opposite direction to the cyclical movements of the formal economy - in the recession phase it is large in size, and in the phase of economic recovery it loses its importance because of the high growth of the official economy (OE). In the recession phase it acts as a kind of social shock-absorber. The resourcefulness and flexibility of the taxpayer vis-à-vis government measures rise with the fall in their standard of living. In order to retain the same purchasing power, and this is particularly characteristic of a highly consumptionoriented society like Croatia, taxpayers resort to various methods for the avoidance of taxation. Working in the grey economy is not considered by quite everyone as a negative phenomenon ${ }^{4}$ for other reasons as well. That is, work in the UE is considered a better choice than passivity in the labour market, since in this sector too some added value is after all created.

However, companies or entrepreneurs that get involved in the UE in order to avoid paying taxes lose their connections with the official sources of financing, they reduce the capital intensiveness of their production and do business in a much shorter time span. Apart from that, because of the shortfall in taxation revenue, the government is forced to reduce its long-term, mainly productive investment because of the short-term less productive investments of the tax defaulters; result of which is smaller than the potential long-term rate of growth.

\subsection{The Appearance Forms of Tax Evasion}

Tax evasion appears in the Republic of Croatia in various forms. In connection with income tax it is the consequence of working in underground economy and wage payments in cash or in kind, being reported as at the minimum wage, while the rest of the income being paid in cash, payments via the student labour centre and author's fees because of the lower rates of taxation and so on. New models of avoiding contributions also include fringe benefits. An example is the payment of the profit share of a firm for management board members, the right to free stock entitlements and so on, at the expense of wages from employment. Although the 2000 Personal Income Tax Law ${ }^{5}$ expanded the definition of wage employment to the sum of regular income from work, life insurance premiums, scholarships,

\footnotetext{
${ }^{3}$ An increase of the index of regulation by $1 \%$ (from 1 to 5 , where five is the most regulated economy) leads to a 10 per cent increase of the grey economy (Schneider, 2000).

${ }^{4}$ According to the neo-classical theory the UE responds to the demand of small tradesmen and service providers, thus contributing to the dynamism and entrepreneurial spirit in the economy, and even to increased competitiveness. In addition, some empirical research shows that more than $50 \%$ of the income made in the UE is spent in the OE with positive effects on the collection of indirect taxes and growth. The problem is that even with the assumption of an equal level of productivity in the two economies, in the small enterprise sector the growth of the underground sector is limited.

${ }^{5}$ Official Gazette 127/2000.
} 
pensions, and income in kind (getting the use of a firm car for private purposes, subsidised interest for housing loans, the use of company owned flats for free or at lower than the market rate), still, a profit share for management board members is considered income derived from capital, which is not subject to the payment of contributions.

A figure that in the most recent times has signalised an increase in the avoidance of tax liabilities is the amount of fees for work done (a Institute for Payment figure), which, apart from author's fees (or royalties) include payments done via the student labour centre, severance pay, subsistence, fees to management board members and the like. All these are forms of the tax avoidance, and are on the very edge of being classified as tax evasion, if they are remuneration for regular but underpaid work. The question, then, is how much a rigid labour legislation and high labour costs, above the costs of wages, have contributed to a greater inclination among employers to resort to these forms of wage payments.

Profit tax payers often report greater material costs via padded travel expenses, invoices issued without any purchase being made, the payment of fees for authors' work or for services rendered (market research, administrative work and so on), and in this way reduce the profit. Legal avoidance of profit tax up to 2001 was carried through the application of the protective interest rate on company assets, and the application of accelerated depreciation rates. After the acceptance of the new Profit Tax in $2001^{6}$ the legal tax avoidance was additionally permitted by the tax exemptions on investment into the capital assets of the firm and through taking on new staff.

Real estate sales tax evasion is hard to measure since there are no adequate publicly available figures. However, in practice, undervaluation of the price of residential or commercial premises is extremely frequent.

The fiscal abundance of value added tax derives from the broad tax base of this tax (there are very few exemptions), a mechanism of collection that makes tax evasion more difficult, and an almost unified and relatively high tax rate $(22 \%)$. How much in fact has the self-control element in this tax, which is paid according to the credit method, managed to reduce the evasion of the tax on the sale of goods and services since 1998? Although VAT has introduced a certain amount of self-checking among the taxpayers, three years after its inauguration, the economy has already found ways of avoiding it. Nonpayment of VAT is common in the service sector, in which almost all transactions are in cash, and trade and operations are often not registered in the books and stay outside the VAT system. The introduction of a zero-rate, in which it is possible to claim a refund of VAT for all the input items, but without the obligation to charge and pay in VAT, has led to taxpayers finding ways of showing their products as those to which the zero regime applies. The lack of legislative specificity abets such procedures. In the sphere of retail sales, goods that were bought in without an invoice are often sold with sales register receipts with a specification of goods with a zero regime (e.g., instead of the mineral water actually bought, the receipt shows bread).

In connection with other kinds of indirect taxes, examples of evasion can be found in the non-reporting or underreporting of the value of imported goods and services, or in imports making use of privileged customs rates (in the same way as with VAT). An additional example of evasion in foreign trade is the sale of customs privileges for, for example, cars, and the return of a fictitious export to the domestic black market. The best example is the fictitious export of cigarettes that end up on open-air domestic markets, which also entails, among other things, the evasion of excises. However, with a reduction in the overall level of customs rates, the signing of new free-trade agreements and a reduction of prices in the domestic market, customs revenues, hence their evasion too, are becoming negligible.

${ }^{6}$ Ibid. 


\section{AN ESTIMATE OF TAX EVASION IN CROATIA FOR THE 1994-2000 PERIOD}

The stability of a tax system is an important factor in the reduction of tax evasion. The transitional environment, however, with its dynamics and series of changes in the taxation and economic system has a negative effect on the reduction of tax evasion. The appearance of the small firm sector, the rapid entry into and exit from the market, an inadequate legal system that adjusts only slowly to rapid transitional changes and the number of institutional reforms lead to a short term loss of a certain amount of public revenue. In conditions in which the tax system has to adjust to the market economy, the tax basis broadens, new taxes are brought in, old ones are abolished and tax rates are changed, it is hard to make reliable conclusions about the amount of tax evasion. The problem is more pronounced through the discrepancies in the statistical monitoring of the macroeconomic aggregates, that is, the bases for the collection of some kinds of taxes.

During the nineties, the Croatian tax system went through a number of reforms. Reduction of the general sales tax rate, abolition of the tax on the sale of raw material and capital goods, the simplification of the collection of custom duties through the reduction of the tariff numbers and the number of rates $^{7}$, and the introduction of excises and, finally in 1998, value added tax, are features of the reforms in indirect domestic taxes. The reform of direct taxes started with the introduction of a new system of taxing income and profit from 1994 (a single profit tax for all resident taxpayers and an income tax with two rates), and the opportunity for local government units to introduce surtax for the financing of their own expenditure. A reduction in the burden from social security contributions and the abolition of some of the contributions (for child benefit and for the water fund in 1998) resulted in the reduction of the costs of labour in the period under observation. The foundation of the Tax Administration and the Financial Police at the beginning of the nineties certainly contributed to a more powerful financial discipline among taxpayers and putting the governmental finances into some order.

In this research an estimate of tax evasion is given on the basis of chosen types of direct and indirect tax revenues. It should be said that data about individual kinds of common taxes ${ }^{8}$, because of the time spans over which taxes are collected in some tax offices and data are processed in the Institute for Payments, are often quite diverse and are subject to retroactive changes. Apart from that, data about overall tax revenue of consolidated general government for 2000 are the author's own estimates, since the Ministry of Finance had not published updated 2000 figures up to the moment of the writing of this paper.

In order to be able to follow the trend of certain tax revenues, it is necessary to determine their macroeconomic base. An adjustment of the number of people employed (in Simulation 2, Chapter 3.1.) was done according to data from a labour force survey (LFS). The number of people employed have been calculated on a full time basis, including persons who work on the black, people who are helping out in their countryside households or who have extra jobs. Because of the shortcomings of domestic statistics in the recording of domestic consumption (although since 1998 household budget surveys have been carried out, they are not used in the calculation of GDP), and, still, because of the failure to include the estimate of the underreported economy into the calculation of the GDP, it is necessary to settle on alternative sizes of the same aggregates. The alternative size of GDP that is used in this research is the estimate from the research work of Madžarević and Mikulić (2002).

\footnotetext{
${ }^{7}$ The average measured custom duty rate according to the customs tariff of 1995 was $12 \%$, while in 2000 it was 7\% (Galinec, 2002).

${ }^{8}$ The common taxes are income tax, profit tax and tax on the sale of real estate, that are shared between central and local government.
} 
Table 1 Shares of the Consolidated General Government (CGG) Revenue in Official and Estimated GDP

\begin{tabular}{|l|r|r|r|r|r|r|r|}
\hline Year & 1994 & 1995 & 1996 & 1997 & 1998 & 1999 & 2000 \\
\hline Official GDP (mil. HRK) & 87,441 & 98,382 & 107,255 & 123,812 & 137,604 & 142,700 & 157,511 \\
Total revenue and grants (\%) & 45.6 & 47.5 & 49.7 & 48.3 & 51.5 & 48.2 & 45.8 \\
Tax revenue (\%) & 43.2 & 44.4 & 44.4 & 43.0 & 46.9 & 43.7 & 41.4 \\
Estimated GDP* (mil. HRK) & 109,695 & 116,462 & 124,749 & 137,900 & 150,149 & 154,701 & 168,238 \\
Total revenue and grants (\%) & 36.3 & 40.2 & 42.7 & 43.4 & 47.2 & 44.5 & 42.9 \\
Tax revenue (\%) & 34.4 & 37.5 & 38.2 & 38.6 & 43.0 & 40.3 & 38.7 \\
\hline
\end{tabular}

- Revenue from privatisation excluded from the total revenue

*Estimate of Madžarević and Mikulić (2002).

If we compare the share of the CGG revenue in the official and in the estimated GDP (Table 1), more or less equal trends of average tax burden are visible - a growth of the tax burden up to 1998 and an easing of the burden in the next two years of about $5 \%$ of GDP. The failure to include estimates of the grey economy in the calculation of GDP definitely suggests its underestimation, and the point about the lower effective than the official tax burden is useful information in the estimation of the competitiveness of the economy. The share of registered total and tax revenue in such a GDP moves at the level of 9 to 3 percentage points lower than in the official GDP.

The value of the adjusted GDP on the basis of which tax evasion has been calculated is still probably underestimated, because adjustments have been carried out only on the item of personal consumption, while personal imports, fictitious exports, the underrating of investment and the like have not been estimated for the simple reason that such data are unavailable.

\subsection{Income Tax and Social Security Contributions}

The Croatian economy is only just going through restructuring, though with a very slow pace. The chances of getting a job in the official sector are restricted, while official sector is incapable of absorbing the unemployed labour force registered in the employment centres because of the restructuring process. Official unemployment is high, and rising. The structure of the unemployed shows a large share of long-term unemployed, and the reduced abilities to get re-employed (more than $50 \%$ of unemployed in the employment centres have been there for more than one year). Unemployment is concentrated in the group of people with a low level of education and people without job experience. A large number of those who are still unemployed after a long period of job seeking have lost their motivation actively to look for employment. The result is the very low official level of employment, of $43 \%{ }^{9}$

Some of the causes of this state of affairs are the high costs of labour, the high level of protection for those in work, and the inadequately developed SME sector, which is the biggest generator of new jobs even in developed countries. An important dimension of the feeble functioning of the labour market is its poor ability to adapt to supply and demand shocks in the economy. Because of the very high protection given to workers and the rigid labour legislation, companies cannot make a timely adjustment to market shocks by adjustments in the number and structure of the workforce. It is expensive to fire workers, as well as time-consuming and complicated ${ }^{10}$, which discourages employers

\footnotetext{
${ }^{9}$ The rate shows the percentage of those actually employed within the population capable to work. Poland, with a view similar unemployment rate, has an employment rate of $48 \%$.

${ }^{10}$ In Croatia the notice period is six months, while in Europe the average is three months. The minimum redundancy payment comes to half a monthly pay for one year of working service, and there is no upper limit, while in almost all European countries there is a ceiling, and the maximum redundancy payment is equivalent to one-third a monthly salary per year of working services.
} 
from hiring new labour during a time of company expansion, for they know that it will be impossible to reduce the number of workers in time of stagnation or recession.

One more reason for the low level of employment can be found in the restrictions concerning the lawful use of the short-term and other flexible forms of employment contract. All these things have an effect on the reduction of job creation in the official sector, and have a negative influence on the restructuring of firms. The consequence of these distortions in the official labour market in the form of high indirect costs of labour and excessive regulation of labour relations is the high level of the grey economy.

Tax evasion in these kinds of tax is mainly not the consequence of the evasion of income tax, since it has a very low effective rate (in 2000 it came to about $9 \%$ ). The high personal allowances $(1,250$ kuna increased by the coefficients of dependents), three relatively low marginal rates $(15,25$ and $35 \%)$ and the opportunity for flat-rate deductions of costs of 25 and $40 \%$ for author's fees and the income of freelance artists give sufficiently large exemptions and reduce the incidence of the evasion of income tax. The problem is more concerned with the still relatively large social security contributions (the contribution rate in 2000 came to $20.6 \%$ or $37.2 \%$ if one adds the contributions paid by employers, while in 1994 it was $47.375 \%$ ) (Table 2).

Table 2 The Wedge Between Total Labour Costs and Net Wages

\begin{tabular}{|l|r|r|r|r|r|r|r|r|}
\hline & 1994 & 1995 & 1996 & 1997 & 1998 & 1999 & 2000 & 2001 \\
\hline Total employer costs* & $\mathbf{1 2 3 , 0 2 5}$ & $\mathbf{1 2 1 , 7 7 5}$ & $\mathbf{1 2 1 , 7 7 5}$ & $\mathbf{1 2 1 , 7 7 5}$ & $\mathbf{1 2 0 , 9 7 5}$ & $\mathbf{1 2 0 , 9 7 5}$ & $\mathbf{1 1 6 , 9 7 5}$ & $\mathbf{1 1 6 , 6}$ \\
\hline Gross pay of employee & $\mathbf{1 0 0}$ & $\mathbf{1 0 0}$ & $\mathbf{1 0 0}$ & $\mathbf{1 0 0}$ & $\mathbf{1 0 0}$ & $\mathbf{1 0 0}$ & $\mathbf{1 0 0}$ & $\mathbf{1 0 0}$ \\
\hline o/w social security contributions & 24.35 & 22.8 & 22.8 & 22.8 & 20.6 & 20.6 & 20.6 & 20.6 \\
\hline o/w income tax & 17.75 & 14.2 & 14.5 & 12.4 & 14.5 & 12.1 & 11.1 & 9.3 \\
\hline Net pay of employee & $\mathbf{5 7 . 9}$ & $\mathbf{6 3}$ & $\mathbf{6 2 . 7}$ & $\mathbf{6 4 . 8}$ & $\mathbf{6 4 . 9}$ & $\mathbf{6 7 . 3}$ & $\mathbf{6 8 . 3 1}$ & $\mathbf{7 0 . 0 8}$ \\
\hline Share of net pay in total cots of employer & 47.1 & 51.7 & 51.5 & 53.2 & 53.6 & 55.6 & 58.4 & 60,1 \\
\hline Total costs of employer as percent of net pay & 212.5 & 193.3 & 194.2 & 187.9 & 186.4 & 179.8 & 171.2 & 166,4 \\
\hline
\end{tabular}

*Including employer's contributions

Source: Ministry of Finance, Central Bureau of Statistics (CBS)

In spite of the long-term reduction in the tax burden on wages, employee's contributions are still $10 \%$ greater than the developed OECD country average. ${ }^{11}$ Failure to pay social security contributions is very largely a consequence of the view of the population about the quality and amount of the services provided by the funds (low pensions that have not kept up with the rise in wages, the merely symbolic child benefit, the level of medical services, lower than that of before the transition, the much higher privileged than old-age pensions). Contributions have gained the stigma of being a tax, and not a way of ensuring a decent existence in the future or in the event of sickness or unemployment.

We can distinguish several kinds of work in the underground sector: an additional job during or after regular working hours, full or part-time work in the underground sector, and the employment of people who are not allowed to work in the country because they have no work permit. The sector structure of work in the UE suggests that it appears much more frequently in the agriculture and service sectors, particularly in commerce, construction, catering, tourism and small trades. Empirical research confirms the greater share of unreported labour in rural areas, and in the SME sector.

Chart 1 shows the shares of taxpayers who are reported as being at the minimum level for health and pension insurance in the overall employed population per sector at the end of 2000. The minimum base is set in such a way so as at least to partially adjust the payment of contributions with the guaranteed minimum pensions. Since contributions on the minimum base cover only $30 \%$ of the minimum

\footnotetext{
${ }^{11}$ Only Germany, Netherlands and Austria, with 21, 27 and 18\% have similar employee contributions. The total employer and employee contributions at the level of $37.2 \%$ are among the highest, again as compared with OECD countries (source: OECD statistics). Greater total contributions are found only in Hungary and Austria, with 40 and $38 \%$ respectively. Germany is at $34 \%$.
} 
pension, this is a kind of subsidy that was immediately recognised by tax evaders as a personal gain. The data are taken over from the Institute for Payments, and are thus real payments. Apart from the fishing industry, which departs markedly from the sample, almost all the service industries (construction, retail and wholesale trade, hotels and catering, real estate agency work and other personal services) have an over-the-average share ${ }^{12}$ of employees reported as being on the minimum wage. The distribution of income in some sectors additionally emphasizes the evasion of direct taxes, because in some sectors there is a marked accumulation of taxpayers in the up to 1,700 kuna bracket.

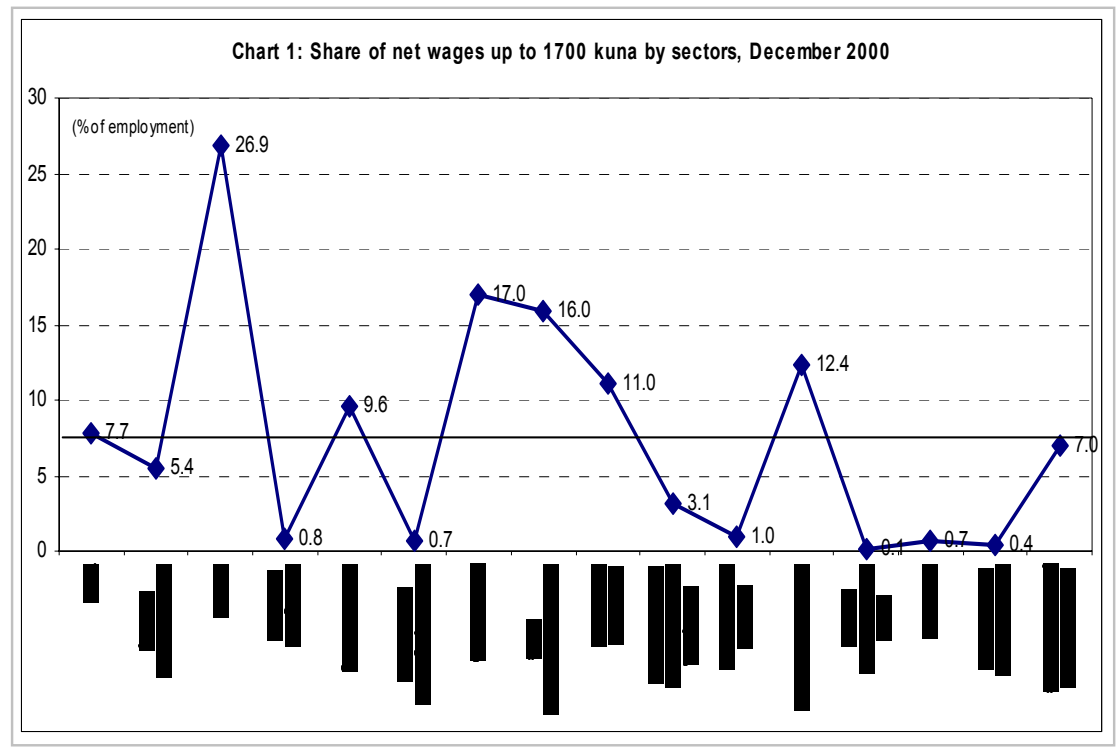

The amount of unpaid tax largely depends on the sector in which someone works. If we look at the ownership structure of companies in December 2000 (Chart 2), it can be seen that the division of income in legal entities with majority state ownership has a much more pyramidal form than the distribution of income in private firms.

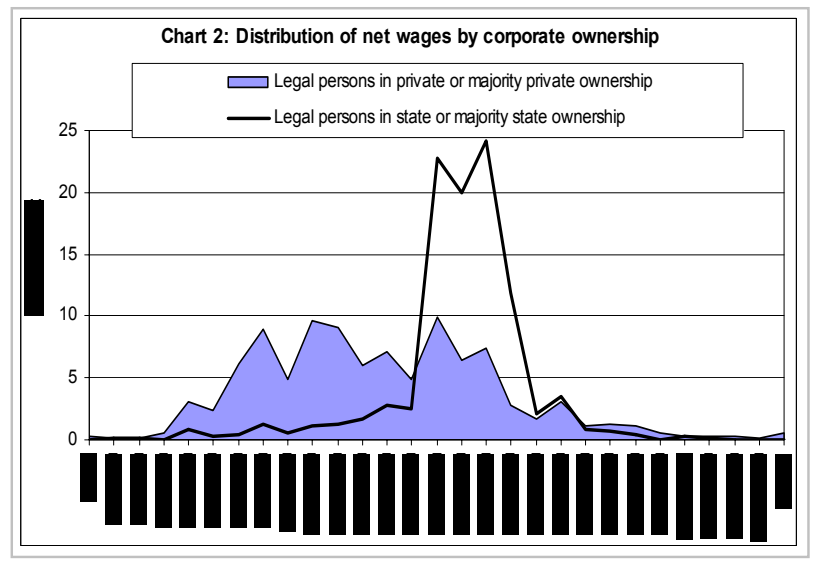

\footnotetext{
${ }^{12}$ The average is $7.7 \%$.
} 
The majority of wages in the state owned firms lies between 3,000 and 5,000 kuna, while in the private firms a considerable amount of wages falls around 1,700 kuna, settled in the economy as the minimum wage (12.7\% as against $1.8 \%$ in state-owned firms). From Institute for Payments' figure about wages in firms according to their size it appears that large and medium-sized firms have a very similar distribution of wages (also like state firms), while the distribution of wages in small firms recalls that in firms that are privately owned as many as $17 \%$ of all employees are reported as having 1,700 kuna a month (Chart 3).

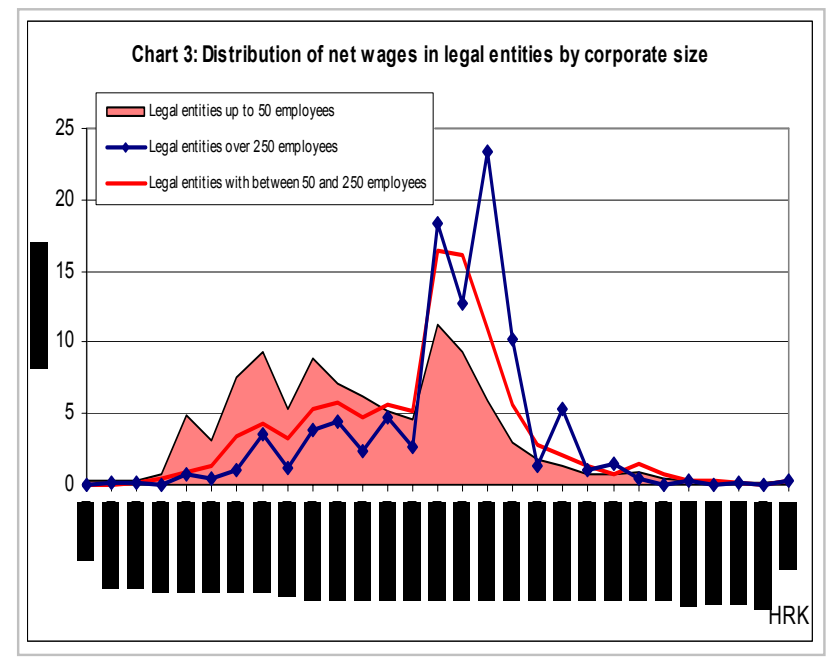

Simulation 1 The trends described lead us to the following assumptions about the estimate of tax evasion:

- the non-payment of tax is smaller in large companies because of the scale of their operations, the need to keep detailed accounts and to pay via giro accounts;

- large companies are mainly privatised or are still in public or perhaps mixed ownership and thus have a more developed culture of the payment of taxes;

- the number of self-employed workers or entrepreneurs would not have increased in the recent years if their earnings were not higher or at least the same as what the average employee of the large firm makes;

- the possibilities of evading tax in small or medium-sized companies are much greater because of their flexibility in procurement, the type of end users for their products and services, and because they are invisible to the tax officials. That is, it is much harder and more expensive to control a large number of business entities paying small amounts of tax than the larger and more fiscally generous taxpayers.

Such assumptions allow us, in Simulation 1, to equate the amount of average wages of small and medium sized companies with the level of average wages paid out in large companies. ${ }^{13}$

The kind of extra works that are subject only to the payment of tax, but avoid the payment of contributions, are works on a fee basis, jobs done via the student employment centre, remuneration for members of management and supervisory boards, and other kinds of remuneration for work done (Institute for Payments' data). Thus, these kinds of income are price-competitive with other kinds of income. The share of such remunerations in totally paid out wages is rising with time, and in 2000 came to $18.1 \%$ of the sum of gross wages. If we look at the shares of such expenditures according to

\footnotetext{
${ }^{13}$ The estimates have been made on the basis of Institute for Payments' figures about the amount of paid out gross and net wages, and the number of employed according to number of hours worked.
} 
company size, the greatest share of remunerations of this kind is paid out precisely in small companies, i.e., as much as $20.5 \%$ of all the wage bill paid out in such companies. Most small companies are registered in the service industries, the provisions for the hiring and firing of workers are simpler, and the only motivation for this kind of employment is to reduce the tax for the labour force.

Thus, in Simulation 1, we can adjust the total new gross wage bill by the fees and royalties paid out, student labour centre payments, and other remunerations to employees (which range around $4-5 \%$ of GDP in the period under observation). In this manner, the estimate of evasion will include the estimate of the avoidance of contributions, which payments via the student work centre, fee based works, insurance premiums paid by employers and so on mainly are. Table 3 shows the results of such estimate.

Table 3 Evasion of Income Tax and Contributions (Simulation 1)

\begin{tabular}{|l|r|r|r|r|r|r|r|}
\hline Simulation 1 & 1994 & 1995 & 1996 & 1997 & 1998 & 1999 & 2000 \\
\hline $\begin{array}{l}\text { Gross and net wages paid } \\
\text { out in large firms (in HRK) }\end{array}$ & $2525 / 1390$ & $3363 / 1895$ & $3994 / 2230$ & $4626 / 2567$ & $5117 / 2811$ & $5506 / 3126$ & $5741 / 3373$ \\
\hline GDP (mil. HRK)* & 87,441 & 98,382 & 107,255 & 123,812 & 137,604 & 142,700 & 157,511 \\
\hline $\begin{array}{l}\text { Income tax and } \\
\text { contributions paid (mil. } \\
\text { HRK) }\end{array}$ & 13,638 & 15,874 & 18,221 & 18,757 & 20,120 & 19,629 & 20,473 \\
\hline $\begin{array}{l}\text { Potential income tax and } \\
\text { contributions (mil. HRK) }\end{array}$ & 16,992 & 19,206 & 22,121 & 23,792 & 25,373 & 25,217 & 26,863 \\
\hline $\begin{array}{l}\text { Tax evaded (mil. HRK) } \\
\text { Share of income tax, } \\
\text { surtax and contribution } \\
\text { evasion in GDP }\end{array}$ & 3,354 & 3,332 & 3,899 & 5,035 & 5,253 & 5,588 & 6,389 \\
\hline $\begin{array}{l}\text { Share of income tax, surtax } \\
\text { and contribution evasion in } \\
\text { taxes and contributions } \\
\text { actually paid }\end{array}$ & $24.6 \%$ & $21.0 \%$ & $21.4 \%$ & $26.8 \%$ & $26.1 \%$ & $28.5 \%$ & $31.2 \%$ \\
\hline * & $\mathbf{3 . 4 \%}$ & $\mathbf{3 . 6 \%}$ & $\mathbf{4 . 1 \%}$ & $\mathbf{3 . 8 \%}$ & $\mathbf{3 . 9 \%}$ & $\mathbf{4 . 1 \%}$ \\
\hline
\end{tabular}

The estimate of the evasion in Simulation 1 is still an underestimation because of the wages of unreported employees and all those who are employed by physical persons without a giro account in Institute for Payments (physical persons were not obliged to open the account in the Institute for Payments).

The number of employed, according to number of hours worked (Institute for Payments figure), in all economy in 1994 was 777,910, while in 2000 was 744,825. From 1999 the calculation has included craftsmen who have accounts in Institute for Payments. The amount of wage of employed people in Simulation 1 is equal to the average wage paid in the large firms, which is still considerably lower (26\%) than that in the public services. The calculation includes only employees' and not employers' contributions. Inclusion of the employers' contributions would increase the amount of the evasion by about a third.

From the results of the simulation a constant growth in the nominal amount of tax evasion can be seen, as well as its fairly stagnant percentage movement in GDP of between 3.6 and $4.1 \%$. In 2000, the government and the fund would have gathered about 6.4 billion kuna more contributions and taxes if the small and medium-sized enterprises and craftsmen had reported their employees or themselves as having a net wage of 3,373 kuna (the average wage in the large companies), and if, instead of through the form of various remunerations, they had paid their employees via regular salary payments.

Because of the economy of scale and the greater capital intensiveness of the large companies it is not entirely justified to assume that the average wage is the same in all sectors of the economy. Another 
drawback of the method is the lack of adjustment of the numbers of reported employment. Therefore we should try to find an alternative method.

Simulation 2 The unsatisfactory statistical coverage of employment to date carried out by official statistics (individual farmers are not included, and neither are people in the ministries of defence and internal affairs) and the Institute for Payments (measures the number of employed persons according to numbers of hours worked, but only in companies that have given in their final accounts) justifies the search for alternative measurements of this indicator. A labour force survey with a much more adequate coverage of the scope of employment began to be carried out only in 1996, and the first quality results were published in 1997. For this reason, for the sake of adjustment of the number of employed persons up to 1996, the number of actively insured persons will be used, a figure from the Croatian Institute for Pension and Disability Insurance. It covers independent entrepreneurs, their employees, independent professionals, people employed in the private sector, farmers and all those employed in the government sector, and can serve as an alternative measure of total employment in Croatia. The number of actively insured persons in 1994 was 1,661,865, rapidly falling by 2000 to 1,380,510 employed people.

Because of increasing disbelief in the pension system, unemployment and the already fully functioning channels of the UE, this figure loses its adequacy and scope as against the real state of employment. For this reason it is worthwhile using the data from the labour force survey that, apart from about regular employees, also give information about associated members of craftsmen's and farmers' households (who help the head of the household to make an income) and about additional activities that already employed deal with. In connection with these two last groups, hours of work have been standardised up to full working time, so as to be comparable with the other data, i.e. that their remunerations can be equated with regular work.

If we assume that:

- the data about actively insured persons up to 1996 and data about employment in the LFS after 1996 give the real measure of employment in Croatia,

- that their monthly wages are equal to average wage in business sector (which are about $30 \%$ lower than public sector wage) and

- the contributions that should have been paid, but which have been written off by a government decision (coming to between 0.5 and $0.3 \%$ of GDP and relate mainly to the shipbuilding and farming sectors), can be excluded from the evasion,

then the share of tax evasion provides the potential upper limit of income tax and contribution evasion (Table 4).

Table 4 The Evasion of Income Tax and Contributions (Simulation 2)

\begin{tabular}{|l|r|r|r|r|r|r|r|}
\hline Simulation 2 & 1994 & 1995 & 1996 & 1997 & 1998 & 1999 & 2000 \\
\hline $\begin{array}{l}\text { Adjusted employment and average } \\
\text { gross/net wages }\end{array}$ & $\begin{array}{r}2213 / \\
1224\end{array}$ & $\begin{array}{r}2948 / \\
1672\end{array}$ & $\begin{array}{r}3471 / \\
1914\end{array}$ & $\begin{array}{r}3886 / \\
2186\end{array}$ & $\begin{array}{r}4286 / \\
2404\end{array}$ & $\begin{array}{r}4501 / \\
2605\end{array}$ & $\begin{array}{r}4569 / \\
2732\end{array}$ \\
\hline GDP (mil. HRK)* & 87,441 & 98,382 & 107,255 & 123,812 & 137,604 & 142,700 & 157,511 \\
\hline $\begin{array}{l}\text { Income tax and contributions paid } \\
\text { (mil. HRK) }\end{array}$ & 13,638 & 15,874 & 18,221 & 18,757 & 20,120 & 19,629 & 20,473 \\
\hline $\begin{array}{l}\text { Potential income tax and } \\
\text { contributions (mil. HRK) }\end{array}$ & 19,249 & 23,474 & 27,115 & 29,448 & 32,715 & 31,516 & 30,039 \\
\hline Tax evaded (mil HRK) & 5,611 & 7,600 & 8,894 & 10,691 & 12,594 & 11,887 & 9,565 \\
\hline Tax evasion, as \% of GDP * & $\mathbf{6 . 4 \%}$ & $\mathbf{7 . 7 \%}$ & $\mathbf{8 . 3 \%}$ & $\mathbf{8 . 6 \%}$ & $\mathbf{9 . 2 \%}$ & $\mathbf{8 . 3 \%}$ & $\mathbf{6 . 1 \%}$ \\
\hline $\begin{array}{l}\text { Evasion as \% of taxes and } \\
\text { contributions actually paid* }\end{array}$ & $41.1 \%$ & $47.9 \%$ & $48.8 \%$ & $57.0 \%$ & $62.6 \%$ & $60.6 \%$ & $46.7 \%$ \\
\hline
\end{tabular}

*after adjustment for write-offs and avoidance of contributions

Source: CBS, 2001. 
Simulation 1 gives the lower limit of the evasion of the observed direct taxes, while Simulation 2 gives the upper limit of the estimate. In Simulation 1 the relative level of tax evasion is fairly constant, but in Simulation 2 evasion rises considerably up to 1998, after which there is a visible strong fall of as much as $3 \%$ of GDP in only two years. In 2000 the estimates converge to a great extent. Why was there a break in 1998? One of the causes was certainly the reduction in the costs of labour by the abolition of the water fund contribution (0.8\%) and the child benefit contribution (2.2\%) in June 1998. In 2000, evasion is again markedly reduced, which also coincides with a reduction of the total cost of work because of a lowering of the contributions for health and pension insurance ( 2 plus $2 \%$ ). Because of the bankruptcies that were initiated and also because the government started to pay some of its outstanding obligations, there was also a considerable reduction in the number of employed people who were at work but not receiving any wages, from about 180,000 in 1998 to 90,000 in 2000.

\subsection{Profit Tax}

It is a difficult task to estimate the evasion of profit tax if one takes into consideration the fact that there are many ways of increasing business costs and thus avoiding a tax liability. It is an additional problem that the rate of profit tax up to 1997 was the same as the lower marginal rate of income tax $(25 \%)$, which resulted in physical persons - entrepreneurs paying the minimum wages, and making bigger profits payments. Although in 1997 the profit tax rate was increased to the upper marginal rate for income tax (35\%), tax exemptions brought in at the same time reduced the effective rate even below the lower income tax rate. Transferring income to profit for the sake of paying lower taxes additionally increased the growth of profit tax revenue in the 1995-2000 period. That is, the nominal rise in GDP in that period came to $63.2 \%$, and the rise in revenue from profit tax to $97.6 \%$.

Profit tax is a variable that is highly dependent on overall economic activity. By econometric evaluation of real profit tax revenues and its dependence on real $\mathrm{GDP}^{14}$, we arrive at the considerable significance of such a variable as the assumed base for profit tax. GDP is most significant with a lag of 7 to 9 months. In Chart 4 we can see a fairly clear trend up to 1999, after which the tax moves away from the tax base. This means that payments for profit from 1999, which were finalised in May 2000, were substantially affected by the drop in economic activities in 1999. However, the fall in real tax revenue $(-29.8 \%)$ was much greater than the fall in economic activity $(-0.4 \%)$. This brings us to the conclusion that taxpayers made more use of opportunities for reducing or avoiding their tax liabilities.

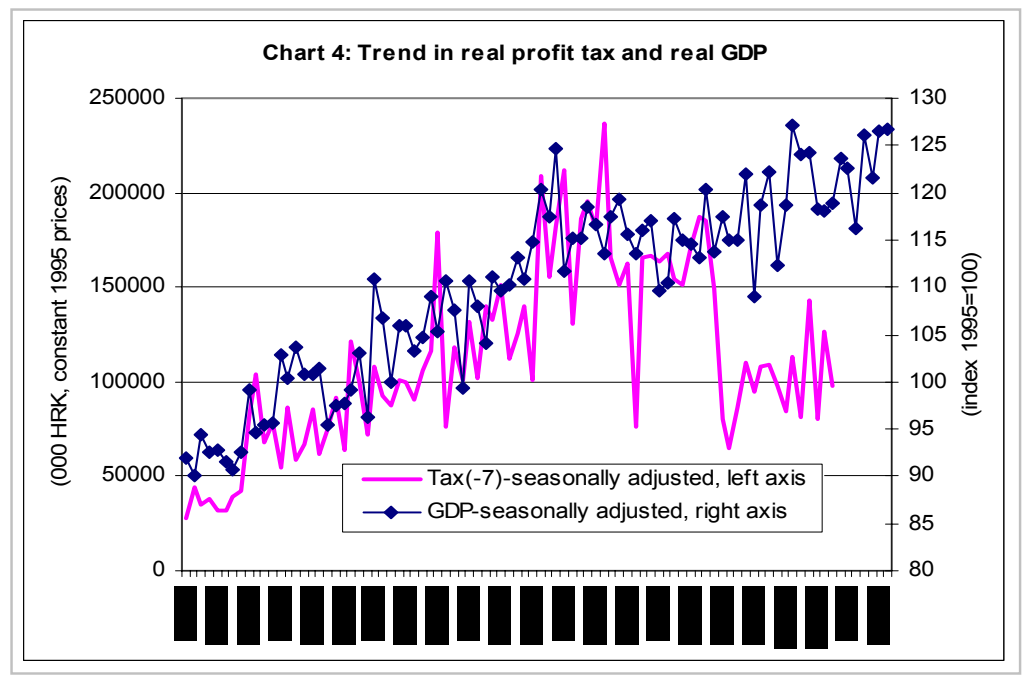

${ }^{14}$ An evaluation of monthly GDP has been done with the application of the seasonal dynamics of industrial production. 
If we apply the evasion estimation method using the same shares of profit tax in the estimated (Madžarević and Mikulić, 2002) and in the official GDP, we will arrive at an estimate of the profit tax evasion of at the consolidated general government level. The results are displayed in Table 5.

Table 5 Estimate of Profit Tax Evasion

\begin{tabular}{|l|r|r|r|r|r|r|r|r|}
\hline Year & 1993 & 1994 & 1995 & 1996 & 1997 & 1998 & 1999 & 2000 \\
\hline GDP (mil. HRK)* & 39,003 & 87,441 & 98,382 & 107,255 & 123,812 & 137,604 & 142,700 & 157,511 \\
\hline $\begin{array}{l}\text { Estimated GDP (mil. } \\
\text { HRK)** }\end{array}$ & 53,387 & 109,695 & 116,462 & 124,749 & 137,900 & 150,149 & 154,701 & 168,238 \\
\hline $\begin{array}{l}\text { Profit tax paid in for t-1 } \\
\text { (mil. HRK) }\end{array}$ & 887 & 1,401 & 1,772 & 2,504 & 3,477 & 3,341 & 2,769 \\
\hline $\begin{array}{l}\text { Potential profit tax for t-1 } \\
\text { (mil. HRK) }\end{array}$ & 1,214 & 1,758 & 2,098 & 2,913 & 3,872 & 3,646 & 3,002 \\
\hline Tax evaded (mil. HRK) & 327 & 357 & 326 & 408 & 396 & 305 & 233 \\
\hline $\begin{array}{l}\text { Evasion of profit tax as } \\
\text { percentage of GDP }\end{array}$ & & $\mathbf{0 . 8 4 \%}$ & $\mathbf{0 . 4 1 \%}$ & $\mathbf{0 . 3 3 \%}$ & $\mathbf{0 . 3 8 \%}$ & $\mathbf{0 . 3 2 \%}$ & $\mathbf{0 . 2 2 \%}$ & $\mathbf{0 . 1 6 \%}$ \\
\hline
\end{tabular}

*Source: $C B S, 2001$.

** Source: Madžarević and Mikulić, 2002.

The evasion of this tax is relatively small and is reducing as a percentage of GDP. But conclusions should be made through an observation of the evasion of other kinds of taxes and the opportunities available for lawful accounting to reduce the tax base. Transferring income into payments of profits because of the lower rate of taxation has largely made it impossible to make any hard and fast conclusions about the evasion of this kind of tax.

Overall evasion of direct taxes could be brought down to a question of two rates, an upper and a lower, which are clearly influenced by trends in the evasion of income tax and contributions.

Table 6 Overall Evasion of Direct Taxes (as percentage of GDP)

\begin{tabular}{|l|c|c|c|c|c|c|c|}
\hline Year & 1994 & 1995 & 1996 & 1997 & 1998 & 1999 & 2000 \\
\hline $\begin{array}{l}\text { Evasion of direct taxes as percentage of GDP } \\
\text { (lower limit) }\end{array}$ & $4.7 \%$ & $3.8 \%$ & $4,0 \%$ & $4.5 \%$ & $4.1 \%$ & $4.1 \%$ & $4.2 \%$ \\
\hline $\begin{array}{l}\text { Evasion of direct taxes as percentage of GDP } \\
\text { (upper limit) }\end{array}$ & $7.3 \%$ & $8.1 \%$ & $8.6 \%$ & $9.0 \%$ & $9.5 \%$ & $8.6 \%$ & $6.2 \%$ \\
\hline
\end{tabular}

\subsection{General Sales Tax and Value Added Tax}

Providing the most abundant budgetary revenue (about 25 to $30 \%$ of the revenue of consolidated general government or about 12 to $15 \%$ of GDP, depending on the year), general sales tax and later VAT, are the most important sources of revenue. At the beginning of 1998, one kind of tax based on the taxation of the turnover in retail trade (although it also involved other phases of the trade chain and accumulated the tax burden in the so-called cascading effect), was successfully replaced by another kind (in which the added value in the economy was taxed via consumption), without there having been any fall in such tax revenue, but on the contrary a rise. The relatively high unified VAT rate, of $22 \%$, and the low number of exemptions (the financial sector, health care, welfare and culture) certainly contributed a lot to the fiscal abundance of this tax.

Since 1998, the revenue share collected through VAT has fallen. The introduction of a zero rate at the end of 1999 on bread, milk, books and some medicines, the further expansion of the zero regime in 
2000 to magazines and cinemas, and since 2001 to packages offered by tour operators from abroad, has led to VAT revenue falling, coming as a percentage of GDP to $13.9 \%$. The expansion of the zero regime has opened up a space for speculations with the registration of a group of products and services, and increasing lobbying pressure for further expansion of distortions in what is actually a qualitative and fiscal revenue-generating system. However, in terms of revenue collected from VAT as a percentage of GDP, Croatia is still the world leader in the collection of such revenue. It is almost impossible to find a country in which VAT revenue is more than $10 \%$ of GDP, not even among countries with a unified rate of more than $22 \%$ (example, Denmark). ${ }^{15}$ In practice, the rule is that revenue obtained from VAT as a percentage of GDP can be expressed as a half of the rate. This means that Croatia, with a rate of $22 \%$, could expect to get $11 \%$ of GDP in its VAT revenue. The real percentage of around $14 \%$, with all reservations and adjustments for the specificity of the Croatian economic system, nevertheless shows that official GDP, the proxy VAT base, is underestimated.

The elasticity of general sales tax and retail sales came to a very high 0.9525 . Because of such a high degree of significance of the link between retail sales and general sales tax in previous research ${ }^{16}$, an adjustment of the retail sector was carried out. In Simulation 2 of the previous research, a new base for the calculation of tax was brought in, which shows the size of personal consumption, estimated on the basis of trends in the total supply of goods and services on the domestic market (domestic production was reduced by the change in inventories, and increased by adjusted net imports) ${ }^{17}$. To this new base, a rate of the tax burden on consumption of about $20 \%$ was applied $^{18}$ and the estimate obtained came to about 3.5\% of GDP in 1995 and 1996. In the meantime, official statistics have published the real level of personal consumption, and this estimate is no longer adequate.

With a change in the type of tax, the tax base too has changed; it is much broader than its predecessor, but does not allow the double taxation of the tax burden in the system. ${ }^{19}$ In order for estimates to be comparable, the following assumptions have been made for a calculation of tax evasion:

- general sales tax/VAT as a percentage of estimated GDP is the same as the percentage of the taxes in official GDP;

- with the adoption of such assumptions, Croatia is still the world champion in the collection of this kind of tax.

\footnotetext{
${ }^{15}$ The annual report of the Ministry of Finance for 1998, the chapter on "The link between revenue from the value added tax and the measure of aggregate activity".

${ }^{16}$ Madžarević (1997).

${ }^{17}$ The estimate of the trends in total supply on the domestic market is explained in more detail in Madžarević and Mikulić (1997).

${ }^{18}$ Dalić, Madžarević and Nestić (1996), "Estimate of the possible effect of the introduction of valued added tax on prices in the Republic of Croatia", Financijska praksa, 20(8), p. 230.

${ }^{19}$ Initial calculation suggested the fiscal and price neutrality of VAT. However, it actually resulted in a one-time increase in prices that phased out in time, and a similar one-off increase in the revenue from this kind of tax, the share of which has also tended to reduce in recent times.
} 
Table 7 Evasion of turnover tax and VAT

\begin{tabular}{|l|r|r|r|r|r|r|r|}
\hline Year & 1994 & 1995 & 1996 & 1997 & 1998 & 1999 & 2000 \\
\hline GDP (mil. HRK)* & 87,441 & 98,382 & 107,255 & 123,812 & 137,604 & 142,700 & 157,511 \\
\hline Estimated GDP (mil. HRK)** & 109,695 & 116,462 & 124,749 & 137,900 & 150,149 & 154,701 & 168,238 \\
\hline $\begin{array}{l}\text { General sales tax and VAT collected } \\
\text { (mil. HRK) }\end{array}$ & 13,107 & 13,374 & 14,204 & 16,374 & 20,228 & 19,830 & 21,825 \\
\hline - as percentage of GDP & 15.0 & 13.6 & 13.2 & 13.2 & 14.7 & 13.9 & 13.9 \\
\hline $\begin{array}{l}\text { Potential general sales tax and VAT } \\
\text { (mil. HRK) }\end{array}$ & 16,443 & 15,832 & 16,521 & 18,237 & 22,072 & 21,498 & 23,312 \\
\hline Tax evaded (mil. HRK) & 3.336 & 2.458 & 2.317 & 1.863 & 1.844 & 1.668 & 1.486 \\
\hline $\begin{array}{l}\text { GST/VAT evasion as percentage of } \\
\text { GDP }\end{array}$ & $\mathbf{3 . 8 \%}$ & $\mathbf{2 . 5 \%}$ & $\mathbf{2 . 2 \%}$ & $\mathbf{1 . 5 \%}$ & $\mathbf{1 . 3 \%}$ & $\mathbf{1 . 2 \%}$ & $\mathbf{0 . 9 \%}$ \\
\hline
\end{tabular}

*Source: $C B S, 2001$.

** Source: Madžarević and Mikulić 2002

Evasion of these taxes, according to the assessment, is constantly going down, and is losing its critical point for public revenue. VAT has without any doubt brought self-controlling mechanism into the system, and has partially removed motivations for evasion. ${ }^{20}$

In data about the inspections of taxpayers we find that the most frequent infringements of the General Sales Tax Law and the VAT Law are non-recording of invoices issued, the non-issue of invoices to customers, not keeping books, inaccurate recording of turnover, failure to list products in inventories during changes in the tax rates, the purchase of raw materials under the heading of equipment (which was valid until the introduction of VAT), as well as other things. In over 70\% of the cases this involves physical persons, craftsmen and entrepreneurs, and about the same percentage relates to the offence of not issuing invoices.

\subsection{Special Taxes - Excises on Tobacco and Tobacco Products}

Soon after they were introduced in July 1994, excises became one of the more important sources of revenue of the State Budget. The share of them in the total taxes of general government in 2000 came to about $10 \%$. Data from tax inspections reveals the existence of the following kinds of violation: inaccurate calculation of the special tax, failure to pay the tax, showing production losses above the statutorily permissible amount, failure to declare the import of products subject to excise, the import of alcohol without the permission of the Central Office of the Tax Administration, the failure to report the activity of producing alcohol, the failure to list reserves, the export of tobacco products without the permission of the Ministry of Finance, the sale of foreign cigarettes without the inspection stamp and suchlike.

Excises will very probably never become the most important tax revenue because of its theoretical base. It is mainly levied on a small number of luxury products that are fiscally generous, but are also simple to calculate and monitor. The importance of these taxes can be seen in the decision of the government to, for example, finance ambitious investment programmes from the excises on petroleum derivatives. The collection of them, then, has to keep up with investment programmes and cannot be allowed to fail. For this reason, the monitoring of these taxes has to be improved, which is possible because there are still relatively few taxpayers liable to pay them.

The most interesting things for the calculation are the excises on tobacco and tobacco products; examples of the evasion of this tax and the black market in tobacco are found daily in the media. Only 2 billion kuna a year are collected from these excises, while there has been a yearly expansion in the

\footnotetext{
${ }^{20}$ However, an important message of the high share of VAT revenue suggests the underestimation of its base GDP. If VAT is taken as a corrective variable of GDP, we arrive at the figure that the underestimation of official GDP in 2000 was about $26 \%$, which would thus be the upper limit of the UE.
} 
exports of tobacco products (from about 70 million kuna in 1996 the export of tobacco products rose to 640 million kuna in 2000). An example of the evasion of this kind of excises is the fictitious export of products that come back into the domestic market unburdened with the amount of the excises. Excises are collected only from products for the domestic market and from imports. Let us suppose:

- that about $50 \%$ of exports of cigarettes return to the Croatian market (starting from 1997, mainly from the "leaky" Croatian borders) and

- we adjust the import of tobacco products in 1995 and 1996 by at least $10 \%$, which is the average calculation of the underestimation of the value of imports (see Galinec, 2001),

then evasion of excises on tobacco and tobacco products expressed as a percentage of GDP comes to between 0.2 and $0.3 \%$ (Table 8 ).

Table 8 Evasion of Tobacco Excises

\begin{tabular}{|l|r|r|r|r|r|r|}
\hline Year & 1995 & 1996 & 1997 & 1998 & 1999 & 2000 \\
\hline GDP (mil. HRK)* & 98,382 & 107,255 & 123,812 & 137,604 & 142,700 & 157,511 \\
\hline $\begin{array}{l}\text { Excises on tobacco and its products } \\
\text { collected (mil. HRK) }\end{array}$ & 1,759 & 2,040 & 2,000 & 1,983 & 1,970 & 2,074 \\
\hline $\begin{array}{l}\text { Potential excises on tobacco and tobacco } \\
\text { products (mil. HRK) }\end{array}$ & 1,777 & 2,054 & 2,300 & 2,211 & 2,246 & 2,563 \\
\hline Tax evaded (mil. HRK) & 18 & 15 & 300 & 227 & 276 & 490 \\
\hline $\begin{array}{l}\text { Evasion of tobacco excises as percentage of } \\
\text { excises on tobacco actually paid }\end{array}$ & $1.0 \%$ & $0.7 \%$ & $15.0 \%$ & $11.5 \%$ & $14.0 \%$ & $23.6 \%$ \\
\hline Evasion as percentage of GDP & $\mathbf{0 . 0} \%$ & $\mathbf{0 . 0} \%$ & $\mathbf{0 . 2} \%$ & $\mathbf{0 . 2} \%$ & $\mathbf{0 . 2 \%}$ & $\mathbf{0 . 3 \%}$ \\
\hline
\end{tabular}

Source: $C B S, 2001$.

That the arbitrary adjustment of the supply of these products on the domestic market is more or less correct is confirmed by Public Health Institute figures about the consumption of tobacco in Croatia ${ }^{21}$. If we multiply the number of packages by the average excise rate, which in 2000 came to $475,050 * 5.4$ (kuna), then the evaded excises as a percentage of the excises on tobacco actually paid comes to $23.7 \%$, which is more or less the same as the figure obtained by the adjustment of the supply.

Further research into the evasion of these taxes requires better statistical monitoring of the production of products subject to excises, an understanding of the production process, and particularly of the percentage of spillage and wastage in this process. Official statistical data about domestic production are disaggregated according to individual kinds of product for which the tax liability can be calculated if the production process of an individual product is understood. These data are not comparable with the figures of the Tax Administration about amounts of product that are taxed with excises.

\footnotetext{
${ }^{21}$ Published in the Euphin database.
} 


\section{INSTEAD OF A CONCLUSION}

\subsection{Commentary on the Estimates}

Through a separate analysis of the evasion of individual taxes for the period 1994-2000, two similar trends can be seen: the lower limit shows a steady reduction in tax evasion (with the exception of 1997), while the upper limit of tax evasion shows a fairly constant trend up to 1998 and a strong fall after that. The two estimates tend to converge in 2000 to a difference of $2 \%$ of GDP. The potential upper and lower level of overall evasion of the consolidated general government taxes is shown in Table 9.

For the exercise of calculating the evasion the short period from 1994 to 2000 has been chosen, because in spite of reforms introduced and their effect on the changing of the tax bases and conclusions about evasion, nevertheless certain estimates can be arrived at. Since there are no reliable data about budgetary revenue before 1994, and those that might be reliable are not comparable, this period has been excluded.

Table 9 Tax Evasion (as \% of GDP)

\begin{tabular}{|l|r|r|r|r|r|r|r|}
\hline Year & 1994 & 1995 & 1996 & 1997 & 1998 & 1999 & 2000 \\
\hline GDP (mil. HRK)* & 87,441 & 98,382 & 107,255 & 123,812 & 137,604 & 142,700 & 157,511 \\
\hline Estimated GDP (mil. HRK)** & 109,695 & 116,462 & 124,749 & 137,900 & 150,149 & 154,701 & 168,238 \\
\hline Tax revenue (mil. HRK) & 37,767 & 43,677 & 47,962 & 53,282 & 64,506 & 62,400 & 65,181 \\
\hline Tax revenue (as \% of GDP) & $43.2 \%$ & $44.4 \%$ & $44.7 \%$ & $43.0 \%$ & $46.9 \%$ & $43.7 \%$ & $41.4 \%$ \\
\hline Tax evasion, lower limit (mil. HRK) & 7,423 & 6,208 & 6,586 & 7,670 & 7,764 & 7,848 & 8,622 \\
\hline $\begin{array}{l}\text { Tax revenue 1, as percentage of estimated } \\
\text { GDP }\end{array}$ & $41.2 \%$ & $42.8 \%$ & $43.7 \%$ & $44.2 \%$ & $48.1 \%$ & $45.4 \%$ & $43.9 \%$ \\
\hline Tax evasion, upper limit (mil. HRK) & 9,680 & 10,477 & 11,581 & 13,326 & 15,106 & 14,147 & 11,798 \\
\hline $\begin{array}{l}\text { Tax revenue 2, as percentage of estimated } \\
\text { GDP }\end{array}$ & $43.3 \%$ & $46.5 \%$ & $47.7 \%$ & $48.3 \%$ & $53.0 \%$ & $49.5 \%$ & $45.8 \%$ \\
\hline Evasion as percentage of GDP, lower limit & $\mathbf{8 . 5 \%}$ & $\mathbf{6 . 3 \%}$ & $\mathbf{6 . 1 \%}$ & $\mathbf{6 . 2 \%}$ & $\mathbf{5 . 6 \%}$ & $\mathbf{5 . 5 \%}$ & $\mathbf{5 . 5 \%}$ \\
\hline Evasion as percentage of GDP, upper limit & $\mathbf{1 1 . 1 \%}$ & $\mathbf{1 0 . 7 \%}$ & $\mathbf{1 0 . 8} \%$ & $\mathbf{1 0 . 8} \%$ & $\mathbf{1 1 . 0} \%$ & $\mathbf{9 . 9 \%}$ & $\mathbf{7 . 5 \%}$ \\
\hline
\end{tabular}

* Souce: CBS, 2001.

** Source: Madžarević and Mikulić, 2001.

The lower limit is obtained as the sum of the lower limit of evasion of direct taxes as in Table 6 and other separate estimates for VAT/general sales tax, and excises on tobacco and tobacco products. Equivalently, the upper limit shows the sum of the upper limit of the evasion of the direct taxes as shown in Table 6 and two estimates for selected types of indirect taxes. The limits of the estimates diverge only because of the two different estimates of evasion of income tax and contributions. 
The lower limit of tax evasion more or less keeps up with the movement of the UE as a percentage of GDP (Chart 5). Until 1997, this link was very strong, while after that, very likely because of a correction of the statistical coverage of the national accounts, there was an artificial reduction of the percentage of the UE, while the estimate of evasion suggests the continued existence of considerable evasion, of about $5.5 \%$ of GDP.

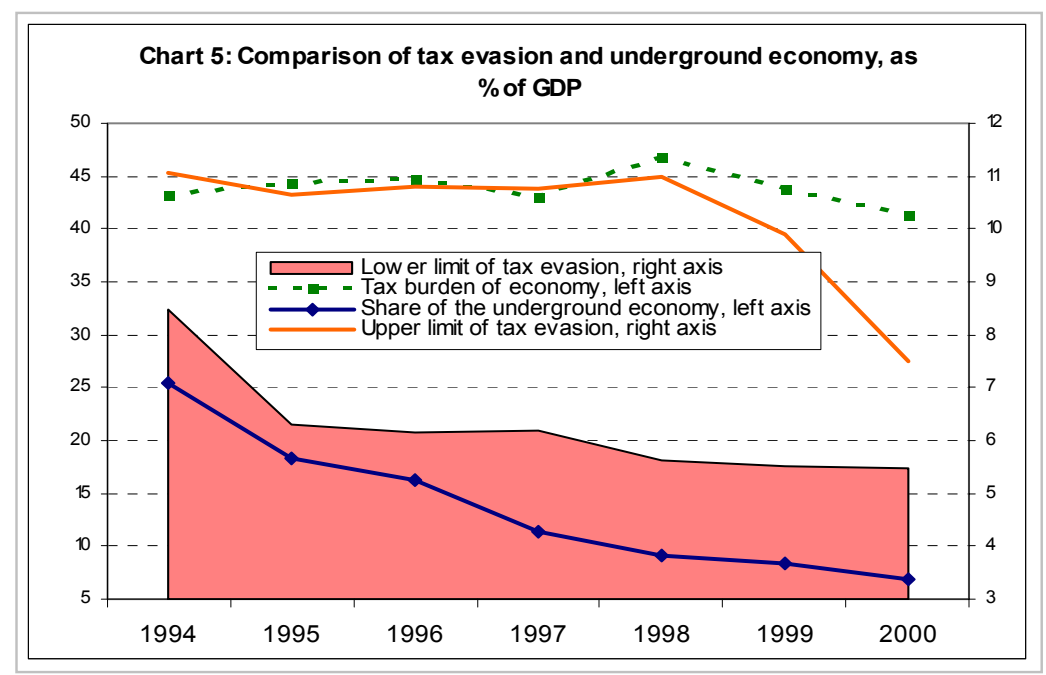

The upper estimate of tax evasion partially follows the trend in tax burden or the alleviation of the tax burden on the economy. And while this trend is fairly even right up to 1997, the growth of the tax burden in 1998, of as much as 3\% of GDP, was accompanied by a smaller rise in evasion. VAT undoubtedly reduced the possibility of the greater evasion that could have been expected from the rise in taxation. During 1998 and the next two years there was a constant reduction in labour costs, the effects of which on the reduction of tax evasion became visible only in 2000. The total reduction of evasion in the 1998-2000 period came to $3.5 \%$ of GDP. The consolidation of the banking system, which caused increased credit expansion, had a great part to play in the reduction of tax evasion in this period. Credit activity was directed at capital products, which in the end changed the structure of household and company consumption in the direction of consumption that is harder not to record. The next major reduction in evasion, this time of income tax and contributions, should come about with the introduction of the capitalised system of pension insurance. In the new system an individual will have a motivation to see the contribution being paid into his own account, which will be increased by the real yield. Through uniformed collection of taxes and contributions there should be an increase in compliance with respect to all those taxpayers who have so far been selective in deciding on what kind of taxes they want to pay, and which not, depending on their own estimation of the quality of service they receive in return.

\subsection{Recommendations for Economic Policy}

The importance of an optimum tax system for the functioning of any state can be seen in the increasing role of the government in economic, social and political life. Econometric models point to the fact that simplification of the administrative procedure has an effect on the willingness to pay taxes, but with a low degree of significance. Nor does the degree of forced collection have any very important correlation with evasion, irrespective of statements that the employment of more tax collectors will bring more revenue to the government (Guy, 1991). Increasing the tax rate increases the taxpayer's inclination towards a higher degree of evasion, and increasing fines will make the informal sector less attractive because it brings in a greater risk of the activity of evasion. Filling the budget with new fines, however, is a sign of the unsound condition of the existing system. The real cure for tax evasion is the prevention of the causes of the grey economy, not prevention of the negative consequence of its 
existence. Some of the major factors that tend to lead to a decision to operate into the grey zone have been stated in Kaufmann, Kaliberda (1996). They are:

- political repression vs. freedom;

- the legal system and institutional mechanism of enforcing the law;

- the degree of administrative control (and a high degree of discretionary decision making) as against the liberalisation of the official economy;

- the official tax burden (taxes, double taxation, constant changes of the tax system);

- macroeconomic instability and a disordered system of payments.

Schneider (2001) is of the opinion that a large number of taxes, broad tax bases, and an increase in allowances make a tax system complex enough for the increase of one tax not to be particularly perceptible, and consequently, the increase in the grey economy being lower than in simple taxation system. This concept is known in economic literature as the fiscal illusion. Schneider even thinks that a larger number of legal tax allowances and exemptions reduces the motivation for doing business in the $\boldsymbol{U E}$ because it provides a larger number of possibilities for the legal avoidance of a tax liability.

The Ministry of Finance recently published the figure of 21 billion kuna of outstanding tax and contribution claims that have not yet been affected by the statute of limitations. With the heralding of increased penalties for defaulting on taxes and the start of a media campaign to raise the consciousness of taxpayers about the need to pay taxes ${ }^{22}$, the government has to be consistent in the collection of old claims. A tax amnesty might have a very dangerous effect on other taxpayers and encourage further defaulting ("if they write it off once, they can write it off again").

If the tax system, the tax administration and inspection become stable, some of the business activities will become part of the formal sector. A tax system that constantly changes is a fertile ground for evasion, and is hard for the tax officials themselves to keep up with. The government has to be a good example to other participants in the market in the way it meets its liabilities. It should also not deal with the non-transparent subsidising of some economic agents in the form of write-offs for tax claims, payment of their debts and so on. Nor should it give in to lobbying for the introduction of untransparent tax subsidies, or in connection with VAT. The quality of this tax lies precisely in its neutrality, fiscal abundance and relatively simple application.

However, a real stimulus to getting into the official economy will be given by the implementation of political stabilisation, privatisation and restructuring of the economy, through which the preconditions for economic growth are created, and hence for private entrepreneurship, increased employment and increased real incomes. An increase of the tax base would make possible a reduction in the tax burden, which would be an additional motivation for the underground economy to get involved in official transactions. Opening the economy up to foreign investors is also important, among other things because they, from the very nature of their position, tend to avoid underground economy operations.

Surveys carried out in Ukrainian firms (Kaufmann and Kaliberda, 1996) that operate on the borders between the UE and the OE say that only about two years after the establishment of macroeconomic stability, the introduction of a modern and stable tax system, the abolition of administrative controls and the liberalisation of the trade regime, will about $50 \%$ of firms decide to reduce their grey activities. The following $33 \%$ would decide to do this in the long term, and $15 \%$ would not change their status in spite of positive changes. This is just additional confirmation that a decision to be engaged in tax evasion is taken very lightly in an unstable environment, while for a process that is irreversible, though promising, tax defaulters need a critical mass of positive reforms and a relatively long period of time.

\footnotetext{
${ }^{22}$ The Tax and Customs Administration introduced, in 2001, a free telephone for the denunciation of defaulters, at the same time explaining to taxpayers that defaulters are cheating them. A similar media campaign has already been carried out by the Ministry of Finance in 1995, under the heading You pay tax to the country you love. The estimated effects of the campaign indicated a $3 \%$ rise in tax revenue in the following period.
} 


\section{LITERATRURE:}

ALAM, A. and SUNDBERG, M., 2001. A Decade of Fiscal Transition, background paper for "A Decade of Transition: Challenges for the Future", forthcoming. Washington : The World Bank.

CHATTOPADHYAY, S., 2000. The Dynamics of Income Growth in the Context of Tax Evasion. In: thesis Macroeconomic Disequilibrium and the Black Economy in the Context of the Stabilization Policy in India. New Delhi: J. Nehru University.

CRNKOVIĆ-POZAIĆ, S. and VUJČIĆ, B., 1998. Country Report Croatia: Employmnet and Labour Market Policies, consultants' report.

DALIĆ, M., MADŽAREVIĆ, S. and NESTIĆ, D., 1996. Procjena mogućeg utjecaja uvođenja poreza na dodanu vrijednost na cijene u Republici Hrvatskoj. Financijska praksa, 20 (8), 325-381.

CBS, 2001. Anketa o potrošnji kućanstava. Priopćenje 13.2.1. Zagreb: Državni zavod za statistiku.

CBS, 1998-2001. Anketa o radnoj snazi. Priopćenje 9.2.7, different numbers. Zagreb: Državni zavod za statistiku.

EILAT, Y. and ZINNES, C., 2000. The Evolution of the Shadow Economy in Transition Countries. CAER II Discussion Paper, No. 83.

EUPHIN DATABASE, www.euphin.dk.

FISHLOW, A. and FRIEDMAN, J., 1994. Tax Evasion, Inflation and Stabilization. Journal of Development Economics, 43 (1), 105-123.

FREY, B. S. and SCHNEIDER, F., 2000. Informal and Underground Economy. In: International Encyclopedia of Social and Behavioral Science, Bd. 12 Economics. Amsterdam: Elsevier Science Publishing Company.

GALINEC, D., 2002. Neslužbeno gospodarstvo u vanjskoj trgovini. Financijska teorija i praksa, 26 (1), $197-212$. GUY, P. B., 1991. Exit: Tax Evasion And Avoidance. In: The Politics of Taxation: A Comaparative Perspective. Cambridge; London: Blackwell, 192-224.

INSTITUTE for Payments, Informacija o financijskim rezultatima poduzetnika $R H$, different numbers. Zagreb: Zavod za platni promet.

KAUFMANN D. and KALIBERDA, A., 1996. Integrating the Unofficial Economy into the Dynamics of PostSocialist Economics: A Framework of Analysis and Evidence. The World Bank, Working Paper 169.

MADŽAREVIĆ, S., 1997. Porezna evazija u Hrvatskoj. Financijska praksa, 21 (1-2), 241-257.

MADŽAREVIĆ, S. and MIKULIĆ, D., 2002. Mjerenje neslužbenog gospodarstva sustavom nacionalnih računa. Financijska teorija i praksa, 26 (1), 31-56.

MINISTRY OF FINANCE, 1996. Načela fiskalne politike Republike Hrvatske u razdoblju 1997-1999: strategija i projekcija. Zagreb: Ministarstvo financija.

MINISTRY OF FINANCE, 1999. Annual Report of the Ministry of Finance for 1998. Zagreb: Ministarstvo financija.

MINISTRY OF FINANCE. Izvješće o rezultatima nadzora kod poreznih obveznika, different numbers. Zagreb: Ministarstvo financija.

MINISTRY OF FINANCE. Monthly Statistical Report, different numbers. Zagreb: Ministarstvo financija.

OECD, 2001. Taxing Wages 1999/00. Paris: OECD.

PERSONAL Income Tax Law, Official Gazette 127/00. Zagreb: Narodne novine.

POMMEREHNE, W. W. and WECK-HANNEMANN, H., 1995. Tax rates, tax administration and income tax evasion in Switzerland. Amsterdam: Kluwer Academic Publishers.

POZO, S., 1996. Exploring the Undergorund Economy. Kalamazoo, Michigan: W.E. Upjohn Institute for Employment Research.

SCHNEIDER, F., 2000. The Value Added of Underground Activities: Size and Measurement of the Shadow Economies and Shadow Economy Labor Force all over the World. IMF Working paper, No. 26.

SCHNEIDER, F. and ENSTE, D. H., 2000. Shadow Economies: Size, Causes and Consequences. Journal of Economic Literature, 38 (1), 74-114.

SCHNEIDER, F., KIRCHLER E. and MACIEJOVSKY, B., 2001. Social Representations on Tax Avoidance, Tax Evasion and Tax Flight: Do Legal Differences Matter? WP No.0104, March 2001.

SCHULZE, G. G., 1994. Misinvoicing Imports: The Interdependence of Tax and Tariff Evasion. Public Finance Quarterly, 22 (3), 335-365.

WEBLEY, P. [et al.], 1991. Tax Evasion: An Experimental Approach. Cambridge: Cambridge University Press. 


\section{INSTITUTE OF PUBLIC FINANCE - OCCASIONAL PAPER SERIES}

No. 1 State Intervention for Growth Promotion in Market Economies. Marina Kesner Škreb, January 1997

No. 2 Estimate of Revenues from the Value Added Tax in the Republic of Croatia. Danijela Kuliš and Žarko Miljenović, October 1997

No. 3 The Unofficial Economy in Croatia: Causes, Size and Consequences. Ivo Bićanić and Katarina Ott, November 1997

No. 4 Price Effects of VAT Introduction in Croatia. Martina Dalić, December 1997

No. 5 Tax Administration Reform in Transition: The Case of Croatia. Katarina Ott, April 1998

No. 6 The Present Sate of the Croatian Public Debt. Zoran Bubaš, December 1998

No. 7 Public Investment in Croatia. Katarina Ott and Anto Bajo, March 1999

No. 8 Welfare Policy and Social Transfers in Croatia. Predrag Bejaković and Alastair McAuley, July 1999

No. 9 Is Unofficial Economy a Source of Corruption? Vedran Šošić and Michael Faulend, November 1999

No.10 Banking Sector Problems: Causes, Resolutions and Consequences. Ljubinko Jankov, March 2000

No.11 Toward a Long-Term Strategy of Economic Development of Croatia:

Where to Begin, What to Do, and How to Do It?, Dubravko Mihaljek, June 2001

No.12 The Underground Economy in Croatia. Katarina Ott, March 2002

No.13 An Estimate of Tax Evasion in Croatia. Sanja Madžarević Šujster, April 2002

No.14 Opportunism, Institutions and Moral Costs: The Socio-Cultural Dimension of the Underground Economy In Croatia 1995-1999. Aleksandar Stulhofer and Ivan Rimac, April 2002

No.15 Dollarisation and the Underground Economy: Accidental Partners? Vedran Šošić and Michael Faulend, April 2002 